\title{
PUBLIC SERVICES IN THE PUBLIC ADMINISTRATION SYSTEM FROM ROMANIA
}

\author{
Ph.D. Student Corneliu Stefan, Dambovita County Council \\ Lecturer Ph.D. Maria-Cristina Stefan, Valahia University from Targoviste, \\ Faculty of Economic Studies, Management Department, e-mail: crys07stefan@yahoo.com
}

\begin{abstract}
The existence and development of a human collectivity is conditioned by its members' gratification (food, dwelling, transport, health, education, culture). In order to satisfy the requirements with social character (dwelling, public transport, health, education, culture), some organizations, which develop social activities, called public services, were set up.
\end{abstract}

The definition of the administrative public service, which constitutes the object of our study, implies a double aspect ${ }^{1}$ :

- From the material point of view, it is a general interest activity, developed by the public administration or by an authorized person in this purpose;

- From the formal point of view, the public service may be defined as assemble of structures of the public administration or of private organizations which develop this type of activity.

From this last aspect, the public administration represents itself a network of public services.

Some part of the administration public services are internal, being represented by the public authorities working departments. Others are external public services, organized under the form of distinctive structures with or without legal status.

The private people who set up public services must be authorized, by the law, to develop this type of activity.

The public services organization is achieved both at the national and local level.

The central public administration is the one that sets up the national interest public services under the form of internal structures (departments) or under the form of some autonomous administrations or public institutions, in case of the external public services.

Therefore, the public service may be defined as a general interest activity developed by a state organization or a local collectivity organization and which is set up by the competent authorities - public and/or local authorities, with the purpose of assuring the requirements' gratification of the community members.

Any public service has the following features:

- $\quad$ satisfies a local utility;

- it is in a continuous process of transformation, depending on the community needs;

- it is in a continuous legal report with the public administration which set it up and which leads it;

- it is submitted to a legal system, controlled by public law principles, which differentiate it from the ones of private companies.

Acting after this type of principles, it contributes to the general interests' satisfaction which it was established for.

\footnotetext{
${ }^{1}$ J. Rivero, J. Waline - Droit administratif, Dalloz, Paris, 1998, p. 429-430;

A. Iorgovan - Administrative Law Treaty, vol. II, Ed. All Beck, 2002, p. 182-184;

I. Alexandru - Public services in: “Administrative Law” (coord. I. Alexandru), Ed. Omnia, 1999, p. 111
} 
Finally, we will make a short presentation of managing the public services. Thus, the term of management defines "the activity of managing all the patrimony elements or only some goods belonging to a person by its representative or all the operations developed by a treasurer, concerning the receiving, keeping and issuing of material goods or money, in a commercial society or institution" 2 .

In the European Book of Local Autonomy, we find the concept of public services management: "through local autonomy it is understood the right and effective capacity of the local public administrations authorities to solve and manage, within the law, in its name and in the local population interest, an important part of the public business".

The management of the public services by a public collectivity raises the problem of behavior of that collectivity. This question is more important today, when the European construction brings more and more in discussion the place of public people in the economic field. In spite of the efforts, the concept of universal public service is ready to finishing off. In this way, two elements are taken into consideration:

- the first is of ideological nature and it is based, on one hand, on the idea that the state is not, through its nature, an enterprising but a controller of the economic life; therefore, it must adopt the position of neutrality towards enterprising and to dedicate itself to the public order missions. On the other hand, the competition becomes, progressively, an objective itself, and not only a simple means;

- the second one is of material nature and refers to the decreasing the public money which puts the state and the decentralized collectivities in a great difficulty of investing and maintaining services more developed for the more exigent citizens, both concerning the quantity and quality of services.

Although in the literature of specialty there are presented for and against arguments, the usage of a specific management of public services is needed.

For arguments are based on the fact that, in the public services, the introduction of a specific management must be achieved on different hierarchic levels, from the superior to the inferior ones. because:

a. The public services were, are and will be indispensable in any country and at any level,

$>$ development of economy and the increase of the developed countries, force the enterprises to run an efficient activity, in order to resist the competition for the internal and external market;

$>$ The increase of the followers and of the power of the people supporting ultra-liberal currents was transposed in practice through an intense critics brought to the former public administrations;

$>$ The present historical period, characterized through the slowing down of the economic development in most economic powers, determines the confrontation of enterprises with new constraints in order to identify new markets and new areas.

$b$. The public services must prove their efficiency and think again their manner of functioning, their missions being more different now-a-days. In order to keep up with the economic development, any public service must update its structures and functions and also to own a certain control to avoid the markets collapses. The confrontation with new problems (increase of social insecurity, endemic unemployment, the problem of poverty, etc.), the public services must think again their structures and adapt itself to the decentralization policy, but also to the working together with ministries, to the need of distributing tasks between central and local services in order to eliminate disfunctionalities, etc. Only in this way they can prove their efficiency and capacity of solving problems and reach their objectives and obtain the desired results for citizen and society.

\footnotetext{
${ }^{2}$ Little encyclopedic dictionary ed. a III-a, Ed. Stiintifica si Enciclopedica, Bucuresti, 1986, p.724
} 
c. The public services must have special frames in the specific management of this field of activity, because the quality of their activity depends on the economic, social and politic environment and the technological one existent at a certain moment. The technological changes from the last decades, office automation and informatics generalization, and their using in the public services, have imposed specialized frames at any level, the revision of the manner of running them, by applying a specific and performing management. These mutations led to the rethinking of the manner of functioning of the public services, of the relations with their beneficiaries, in order to increase the level of competence and the managerial quality.

$d$. The public services must wish themselves to adapt to the market and to the users' requirements - in the new economical-social environment, the public services must adapt the laws of management to their own working conditions, or the changes will be made under the public opinion pressure, but especially of the economic units from their ray of action, which confront themselves with a strong fight of competition.

Therefore:

$>$ The public services must adapt fast, concerning their missions and the efficiency of their activities; these exchanges refer, mainly, to the development of their managerial competences and performances;

$>$ The public clerks must be appreciated after the quality of their services, after their managerial capacity and after their effective results, not after the technical competences.

Against arguments often start from question - why is it necessary the application of some principles of general management in the public administration? - Question asked, especially, by some public clerks situated at different hierarchic levels. This kind of question is based on the following concepts:

a. Management is good for the private sector and cannot be adaptable to the specific problems from the public sector, problem maintained by some public clerks of high hierarchy either because of the lack of knowledge in the management field, or because of the lack of correct perception of the public sector specific in comparison with the private one.

The behavior and preoccupation for the quality of services, of the respect towards the client and of the manners in which the inter-human relations are led, are better reflected in the case of private enterprises than in the public sector which, as it is appreciated in most specialty works, seems to "become older" because it is considered at shelter in front of any change. Knowing these tendencies, it is raised the question of introducing a certain type of specific management to public services, which should have its own constraints in time.

Another argument presented by the public clerks to justify the lack of adapting the management to the public services is the importance of the political factor which brings frequent, sudden and different rigidity in establishing their own objectives.

$b$. It is a method of "manipulation", idea advanced by the clerks from the public services, mainly of those who do not have managerial activity. A certain affirmation is not true because at least three arguments:

1. The management has a psychological dimension discovered by the public clerks who, mainly come from the law, engineering and public accountancy field;

2. The functioning system of the public administration is characterized through certain impersonality because the public clerks are in the service of the citizen, of the common good. This is translated by the fact that every public clerk uses, in its own activity, psychological methods and specific instruments, procedures stipulated in different documents, etc.

In conclusion, the arguments sustained by those who do not consider necessary the introduction of a specific management in the public administration service do not stand because:

$>$ Adopting a specific management to this field supposes the giving up to the old practices of the public clerks who considered themselves "Mighty Gods", showing a total lack of respect towards the citizens; 
The introduction of modern methods of leading and administration facilitates the work of public clerks, making them to work with each other and with the people they have to serve.

During the last 17 years, the public services sector from our country suffered major transformations from the organization, technical and administrative point of view. We cannot say that these transformations occurred as a result of some planned actions or on the ground of a sector strategy adopted by the Government or by another authority; they have a random and conjectural character.

It is important to underline the necessity of creating those conditions through which the consumers may offer the respective services at the European Quality Standards and at accessible prices; in other words, the consumers' existence determines the necessity of the service and not otherwise.

The existent regulations, as well as the ones that will follow, have as purpose the creation of a new coherent legislative frame, which should allow the development of the sector in accordance with the stipulations of the European directives, having as finality the offer of some quality services to the consumers at competitive prices, respecting the principles of long-lasting development, of saving up the resources and the protection of the environment.

Depending on different criteria of classification of the public services, the following groups are highlighted ${ }^{3}$ :

- After the level of accomplishment - national services (interested by the national collectivity) and local services, which are organized at counties, cities, towns and villages level;

- After nature - administrative public services, industrial public services and commercial public services. This typology based on the financing manner has a different type: the administrative public service is intensely perceived as public service, in comparison with the one with commercial and industrial character;

- After the way of organization - public services realized by the public administration authorities and public services realized by the public institutions;

- After the form of property - monopolized public services or administrative status offered only by the administrative institutions which have the monopole over the respective activities, and public services realized by the public and/or private sector - offered both by the public institutions and the private organizations;

- After the object of activity - services of keeping the public order and country defense, financial and fiscal services, education, social assistance and hygiene, of art and culture and economic activities.

- Services of town management are established through Law no. 326/28 ${ }^{\text {th }}$ of June 2001, modified by G.D no 65/2003, which sets the responsibilities of the Romanian Government and of the local and central public administration structures concerning the general policy of the state in this field.

According to this law, the public services of town management are developed under the local public administration authority and their purpose is to supply public utility services ${ }^{4}$.

The public services of town management are grouped in the following categories:

- water supply;

- $\quad$ sewage, the function of these services being set by GD no.32/2002;

- towns cleaning, set by GD no.34/2004;

- centralized heat energy, except the activities of producing heat energy in co-generation;

- public illumination;

- local public transport;

- administration of public town fund;

- administration of public field.

\footnotetext{
${ }^{3}$ Matei, Lucica, op. cit., p. 328 si Prisacaru, V., op. cit., p. 226

${ }^{4}$ Law no. 326/28 June 2001, art. 2, par. 1 and G.D. no. 65/28.08.2003
} 
The public services function on the ground of fundamental rules or principles which must be equally respected by the organization public administration and by the economic agents or the private organizations which these activities of public interests have been entrusted to.

These principles are the followings ${ }^{5}$ :

- principle of equality of all the citizens concerning the access to public services - starts from the principle of equality between citizens in front of law. All the interested persons can ask and benefit from the satisfaction of certain needs, equally, without privileges or discriminations;

- principle of continuity - consists in assuring the on-going function of the public services and belongs to the public service, which must permanently answer to general interests needs;

- adaptability principle of the public services to the new public exigencies of the general interest as a result of the technical, economical and legal changes which are produced in the public services fields, and which influence and determine the new conditions of function of these services;

- principles of neutrality - the public services have as unique purpose the satisfaction of general interest and not of other interests, so that the endorser of a public service cannot use it as an instrument of creating advantages, of some interests or in someone's else disadvantage.

The Organization which controls the well function of town management public services is the National Authority of Controlling the Town Management (N.A.C.T.M.), institution which is under the coordination of the prime-minister and which attributions refer to ${ }^{6}$ :

- attestation/authorization of the town management public services operators;

- gathering information concerning the activity of the town management public services operators and their publishing;

- documents' and registrations' control of the town management public services operators;

- establishing the adjusting mechanism of fees under the conditions of respecting the contracts of management delegation;

- solving the conflicts between the operator and the consumer of town management public services;

- demand ing from the services operators of the programs from the activity improvement, in the case in which their performances do not correspond to the established parameters in the operation license, in the contract of management delegation, respectively;

- withdrawing of the operation license, if the operator of public services refuses to take measures for the improvement of the activity;

The control of the activities accomplished by the public services operators follows:

- the observance of the indicators of performance;

- periodical adjustment of the fees according to the adjusting forms;

- the observance of the Law of Competition;

- assuring the users protection;

- efficient exploitation of the town infrastructure.

The role of coordinating and accomplishing the Government's strategy and policies in the field of consumers protection, through actions meant to prevent and fight the practices which put in danger life, health, security or consumers' economic interests, belongs to the National Authority for Customers' Protection (N.A.C.P.), specialty body of the central public administration, with

\footnotetext{
${ }^{5}$ Trailescu, A., în revista Dreptul, nr. 12/2002, pp. 97-98

${ }^{6}$ Art. 23 din Legea nr. 326/28.06.2001 a serviciilor publice de gospodarie comunala publicata în Monitorul Oficial, Partea I, nr. 359 din 04.07.2001, modificata prin O.G. nr. 65/28.08.2003 publicata în Monitorul Oficial nr. 618/30.08.2003 si O.G. nr.71/29.08.2002 privind organizarea si functionarea serviciilor publice de administrare a domeniului public si privat de interes local, art.23, publicata în M.O., Partea I, nr. 648 din 31/08/2002
} 
legal status, established in 2001 and under the Government's subordination. In its activity, N.A.C.P. collaborates with the other specialty organizations, which are responsible with these attributions in the customers' protection field.

In the public services field, the N.A.C.P. control activity is developed on the ground of the following attributions ${ }^{7}$ :

- controls the observance of the legal dispositions concerning the customers' protection, referring to the products and services security, as well as to the defense of legitimate rights of the customers, making controls in the markets to the producers, importers, distributors, sellers, and at the customs, having access to the places where here are produced, deposited or sold the products or the manner in which the services are performed, as well as the documents referring to them;

- establishes fines and disposes limitation measures for the consequences of the production, performing, import, selling or free offering of some products and services which do not respect the legal dispositions from the fields of activity of the Authority, by applying the principal and complementary contravention sanctions stipulated by the law, informing the penal organizations every time it founds breaking of the penal law;

- controls if the measuring devices used on the market are accompanied by the stipulated documents.

Both at the local and national level, there were organized consultative councils for the customers' protection which group representatives of the authorities of state, industry and customers' groups. The associations for customers' protection mainly inform and teach the customers, but also issue warnings concerning the quality of services to the competent organizations, N.A.C.P. especially.

The assurance of public service quality supposes, sometimes, the application of corrections which are proved to be very important for those services, as part of MDRL. In this sense, we can see the obvious need of mechanisms through which it can be solved, quickly ant correctly, the customers' discontents. However, it must be known that the existence of mechanisms in the public services field may bring bigger benefits if it is driven in the direction of checking the actions of the services suppliers and if it is established a form of quality control, through which it is assured the correct identification and solving of the problems that might appear.

In spite of difficulties, it is a general agreement concerning the necessity of a dialogue with them, as well as on the fact that opinion surveys represent a way of obtaining information concerning the customers' needs and desires.

The measuring of the services quality, as a method of evaluation of the public services, can be made through the sending of a team of experts on the field to make a report - based on interviews with the personnel and the clients - concerning the level of quality as it is defined in a series of quality indicators. This method must be used with caution, because it supposes the breaking of some technical norms of the law.

The control of public services is made by the external organizations of control or inspection for the verification of the information concerning the obtained performances. In countries like Finland, Sweden, UK, it is necessary the independent audit of the report concerning the information about the performance. Thus, at the level of an institution, it is made the comparative analysis of the presented performances with the past ones, as well as with other institutions performances.

In the EU countries, the development of the public services depends on their degree of efficiency, showed in the evaluation process as well as in the existent potential.

The recognition of the public services role in the process of European integration assures the successful accomplishment of the established objectives and the registration of some significant values of the performance indicators.

\footnotetext{
${ }^{7}$ G.D no. 755/03.07.2003 concerning the organization and function of N.A.C.P., art.3, par.1, published in the $O . G$. no. 490 from 08.07.2003
} 
The conclusion that we reached after analyzing institutional frame of the specific component of public services of the MDRL service in Romania can be synthesized as follows: the legal frame in the field is still quite confused and ambiguous, aspect which creates incertitude and blocking at the level of implementing the MDRL system. At this moment there are more normative acts which control the public services field, not existing a unitary frame to include all of them.

Besides the mentioned aspects, it must be specified the fact that there is not a clear tie breaker in the law concerning the public services given to the counties for administration and the ones which are in the towns responsibilities. Sometimes they superimpose this leading to the appearance of some conflicts and big disfunctionalities. Another problem refers to the ambiguous difference concerning the responsibilities belonging exclusively to the county authorities and the ones they are delegated to. The problem concerning who is running and the limits in which the public services are administrated by cunties or towns can only affect the efficiency of local government and allow, in the same time, the accentuation of the policy in the administration.

\section{BIBLIOGRAPHY}

1. Alexandru, I., Public administration. Theories, realities, perspectives, Edition a II-a, Editura Lumina Lex, Bucuresti, 2001

2. Ana, Cristina, „Public services - basic component of the local and regional development management", The 29th Annual Congress of the American Romanian Academy of Arts and Sciences (ARA), University of Applied Sciences, Bochum Germany, september 7-12, 2004, section ECR

3. Androniceanu, Armenia. Public Management. Editura Economica, Bucuresti, 1999

4. Matei, A., Public economy - Economic analysis of the public decisions, Editura Economica, Bucuresti, 2003

5. Matei, Lucica, Public Management, Editura Economica, Bucuresti, 2001

6. Pollitt, Ch., Bouckaert, G., Public Management Reform - a comparative analysis, Oxford: University Press, 2000

7. Trailescu, A., Some considerations concerning the forms of organization of the public services and their legal status, Law Magazine no. 12/2002, pp. 94-97

8. *** Open administration - Initiatives concerning the quality of services, publication made with the OCDE support, Editura Economica, Bucuresti, 2001

9. *** Regards sur 1?actualité, Les services publics à l?heure de la concurrence, La documentation Française, no. 306, décembre 2004

10. Law no. 326/28.06.2001 of town management public services a, published in the Official Gazette, Part I, no. 359 from 04.07.2001, modified through G.D. no. 65/28 august2003 published in the Official Gazette no. 618/30 august 2003

11. Law no. 52/21.01.2003 concerning decisional transparency in the public administration, published in the Official Gazette no. 70 from 3.02.2003

12. Government's Ordinance no.71/29.08.2002 concerning organization and function of the public services of administrating the public and private field of local interest, published in O.G., Part I, no. 648 from 31.08.2002

13. Second progress report on economic and social cohesion. January 2003. www.europa.eu/comm/regional_policy/index_en.htm

14. SÉNAT. $\mathrm{n}^{\circ}$ 82. SESSION ORDINAIRE DE 2000-2001. RAPPORT D'INFORMATION fait au nom de la délégation pour l'Union Européenne (1), sur les services d'intérêt général en Europe. www. europa.eu.int/comm/

15. *** Targoviste town management autonomous status, Organization and function Regulation of the water supply and sewage public services 